\title{
TINGKAT KEPUASAN MAHASISWA TERHADAP LAYANAN KULIAH DARING BERBASIS UBIQUITOUS LEARNING DI TENGAH PANDEMIC COVID - 19 (STUDI KASUS :MAHASISWA STIKOM UYELINDO KUPANG)
}

\author{
Gregorius Rinduh Iriane ${ }^{1}$, Petrus Katemba ${ }^{2}$ \\ Program Studi Teknik Informatika D-III STIKOM Uyelindo Kupang \\ E-mail : gregoriusrinduhiriane@gmail.com, petruskatemba@gmail.com
}

\begin{abstract}
One of the serious problems faced by the Institute of Higher Education, STIKOM Uyelindo Kupang in early 2020 was the replacement of the Corona Virus Covid-19 outbreak which involved all academic activities that were canceled and put into effect online teaching and learning processes or online lectures. Online lectures or online-based lecture systems also called e-learning or Online Courses are lecture processes using information and communication technology in this case the internet. Digital-based learning has been developed from E-Learning to M-Learning to U-Learning and to S-Learning or Smart Learning. The method of learning everywhere without difficulty by space and time has become important and breakthroughs in the field of education are often referred to as Ubiquitous Learning. Learning everywhere or U-Learning is a learning technology that can be carried out anywhere and at any time by integrating mobile technology as a supporting tool. an event, impact or things that cause changes to the process that is happening. The results of this study found out the level of student satisfaction with online lecture services based on ubiquitous learning at STIKOM Uyelindo Kupang
\end{abstract}

Keywords: Daring Lecture, Ubiquitous Learning, Covid-19

\section{PENDAHULUAN}

1.1. Latar Belakang

Sistem e-learning kini mulai bergeser dengan munculnya ubiquitous learning (u-learning) yaitu suatu teknologi pembelajaran yang dapat dilakukan dimana saja dan kapan saja dengan menggabungkan kemampuan peralatan seluler dan teknologi contextaware. Ubiquitous Learning atau U-Learning adalah suatu teknologi Pembelajaran yang dapat dilakukan dimana saja dan kapan saja dengan memadukan teknologi mobile sebagai perangat pendukung utama. Apa beda konsep $U$ learning dengan Learning pada umumnya. Pembelajaran konvensional banyak menganut aliran lecturing, dimana pengajar atau dosen menjelaskan didepan kelas dan pembelajar atau mahasiswa mendengarkannya. Materi yang diberikan juga sama untuk semua mahasiswa. Pada U-Learning, pembelajaran di inisiasi dari mahasiswanya berdasarkan hal yang ingin dia ketahuinya. Banyak yang menyebutnya dengan istilah inquiry learning yaitu belajar berdasarkan pertanyaan, masalah atau scenario tertentu yang di ajukan oleh mahasiswa. Sehingga setiap mahasiswa mungkin saja akan memperoleh pengetahuan baru yang berbeda antara mahasiswa yang satu dengan mahasiswa yang lainnya namun masih dalam topik yang sama. Materi yang di tekankan pada U-Learning adalah Mahasiswa dapat memahami cara melakukan atau mengerjakan sesuatu dari awal sampai selesai, bukan dengan diberikan materi berupa langkah-langkah, melainkan difasilitasi untuk melakukan eksplorasi mandiri terhadap sesuatu objek tertentu, menggali keingintahuan dan mencari jawabannya secara mandiri, dan peran dosen hanya sebagai fasilitator. Salah satu konsep pengajaran yang diterapkan dalam u-learning adalah pengajar atau dosen memberikan arahan secara global, menciptakan suasana belajar 
mandiri dalam ruang eksplorasi seluas-luasnya namun tetap pada rana topik yamg sama.

Sejak wabah Corona Virus/Covid-19 melanda Provinsi Nusa Tenggara Timur berbagai usahapun dilakukan oleh Sekolah Tinggi Manajemen Informatika Komputer STIKOM Uyelindo Kupang agar pelaksanaan Proses belajar mengajar dapat terus dilakukan meskipun tidak secara langsung atau tatap muka salah satunya adalah melaksanakan Proses Pembelajaran Online berbasis Ubiquitous Learning atau U-Learning dengan memanfaatkan fasilitas Internet dengan menggunakan aplikasi-aplikasi pendukung pembelajaran online seperti Googel Class, Zoom, AdLink Sevima, serta Aplikasi IClass yang dikembang oleh Lembaga agar proses pembelajaran online dapat berjalan sebagaimana mestinya. Namun dalam proses perkuliahan online masih terdapat banyak masalah dan kendalah yang ditemukan saat perkuliahan berlansung mulai dari Jaringan Internet yang tidak stabil hingga permasalahan penggunaan media pendukung proses perkuliahan yang kurang memadai. Oleh sebab itu pada penelitan kali ini penulis mencoba mengkaji tingkat kepusan mahasiswa terhadap proses pembelajaran online berbasis u-learning pada STIKOM Uyelindo Kupang selama masa Covid-19 melanda provinsi Nusa Tenggra Timur.

\subsection{Rumusan Masalah}

Berdasarkan uraian latar belakang yang dikemukakan diatas, maka pokok permasalahan yang ditemukan dapat dirumuskan sebagai berikut: Bagaimana Mengetahui Tingkat Kepuasan Mahasiswa terhadap Layanan Kuliah Online atau Daring berbasis Ubiquitous Learning ditengah Pandemic Covid-19.

\subsection{Batasan Masalah}

Agar pembahasan tidak keluar dari topik, maka penulis membatasi permasalahan yang akan dibahas yakni Peneliti hanya akan membahas tentang seberapa besar tingkat kepuasan mahasiswa tentang pelakasanaan proses kuliah online berbasis ulearning dengan menganalisis hasil jawaban kuisioner dari mahasiswa.

\subsection{Tujuan Penelitian}

Adapun Tujuan yang ingin dicapai dari penelitian ini adalah untuk mengetahui tingkat kepuasan mahasiswa terhadap proses pembelajaran online berbasis u-learning sehingga lembagga dapat mengambil Langkah-langkah pasti mengatasi berbagai polimik dan persoalan yang terjadi selama proses kuliah online berlansung.

\section{LANDASAN TEORI}

\subsection{Devinisi Ubiquitous Learning}

IstilahUbiquitous berasal dari bahasa latin yang berarti“ada dimana-mana", istilah ubiquitous sering di gunakan pada bidang teknologi informasi setelah seorang peneliti pada Xerox's Palo Alto Research Center(PARC) bernama Mark Weiser, mengemukakan konsep "ubiquitouscomputing" pada tahun 1988.

Ubiquitous Learning atau U-Learning adalah suatu teknologi Pembelajaran yang dapat dilakukan dimana saja dan kapan saja dengan memadukan teknologi mobile sebagai perangat pendukung utama. U-learning yang bekerja berdasarkan prinsip kemudahan belajar dari mana saja, kapan saja, dan dengan cara apa saja ini telah melahirkan berbagai pendekatan proses pembelajaran inovatif.[2].

\subsection{Definisi Penelitian Ex Post Facto}

Penelitian ex post facto merupakan metode Peneltian yang dimulai dengan melukiskan keadaan sekarang yang dianggap sebagai akibat dari faktorfaktor yang terjadi sebelumnya, kemudian mencoba menyelidiki ke belakang guna menetapkan faktorfaktor yang diduga sebagai penyebab dan sudah beroperasi masa lalu.[4].

\subsection{Manfaat Pembelajaran Daring}

Manfaat pembelajaran daring yaitu:(1) Meningkatkan kadar interaksi pembelajaran antara peserta didik dengan guru atau instruktur (enhance interactivity), (2) Memungkinkan terjadinya interaksi pembelajaran dari mana dan kapan saja (time and place flexibility), (3) Menjangkau peserta didik dalam cakupan yang luas (potential to reach a global audience), (4) Mempermudah penyempurnaan dan penyimpanan materi pembelajaran (easy updating of content as well as archivable capabilities).[1].

\subsection{Karateristik U- Learning}

Karakteristik Ubiquitous diantaranya adalah (1) Peserta tidak akan pernah kehilangan bahan pembelajarannya karena semuanya terekam secara otomatis oleh sistem. Bahan yang terekam misalnya Vidio Streaming di Youtube, history mengerjakan tugas lewat Google Classroom, berkomunikasi 
chatting di WA, di Aplikasi Zoom, di Edlink Sevima dan kirim-kiriman lewat email, terekam terus menerus setiap saat. (2)Semua materi dapat diakses kembali kapanpun diinginkan di seluruh sumber belajar berupa data, video, audio, dan teks. (3) Sistem ini dapat diakses dengan cepat. Peserta dapat secara cepat menemukan jawaban atas materi yang belum dipahami. Yang tidak kalah penting bahwa dengan sistem ini terjadi komunikasi yang multi arah antar peserta dan dosen, peserta dengan peserta bahkan peserta dengan sumber belajar lainnya baik secara sinkronous maupun asinkronus secara tidak langsung atau terjadwal. (4) Mobile phone merupakan komponen perangkat utama dalam pembelajaran berbasis u-learning.

\subsection{Kelebihan Kuliah Online berbasis Ubiquitous Learning}

Kelebihan Kuliah Online berbasis ubiquitous learning antara lain: (1) Para Mahasiswa bisa mengikuti kapanpun dan dimanapun sesuai keinginan dengan koneksi internet yang baik. (2) Menghemat biaya transpotasi karena mahasiswa tidak perlu ke kampus buat mengikuti proses pembelajaran (3) Materi Pembelajaran dapat diakses ulang kapan dan dimana saja serta bisa dipilih sesuai keinginan dan tingkat kemampuan (4) Tanya Jawab dalam perkuliahan bersifat fleksibel karena bisa ditanyakan lewat chattingan baik kepada dosen ataupun rekan sekelas. (5) Waktu masa perkuliahan lebih singkat dpaibandingkan perkulihan yang bersifat konvensional (6) Mahasiswa dituntut untuk lebih bertanggung jawab, kreatif dan juga mandiri sehingga membentuk pribadi yang lebih percaya diri.

\subsection{Kekurangan Kuliah Online berbasis Ubiquitous Learning}

Kekurangan Kuliah Online berbasis Ubiquitous Learning dinataranya: (1) Sangat Tergantung pada Internet, jika jaringan lambat atau kehilangan sinyal maka proses pembelajaran akan menjadi terganggu dan tertinggal. (2) Sangat Tergantung pada sikap displin para mahasiswa, jika kurang disiplin maka pembelajaran akan tertinggal. (3) Dalam Hal interaksi social menjadi sulit karena terbisa sendiri dan hanya mengandalkan perangkat elektronik dalam berkomunikasi (4) Ada beberapa mata kuliah yang mengalami kesulitan apabila mennggunakan proses pembelajaran online. (5) Perangkat Komputer atau Gadget atau Mobile phone minimal harus sudah siap dan memiliki aplikasi pendukung proses pembelajaran online.

\subsection{Strategi Kuliah Online}

Beberapa Strategi Kuliah Online yang dapat diterapkan antara lain: (1) Melakukan Simulasi belajar terhadap materi apa yang akan dipelajari. (2) Mempelajari sesuatu secara tidak langsung. (3) Mempelajari sesuatu dengan mengembangkan ide/gagasan tentang subyek yang hendak di pelajari. (4) Mempelajari sesuatu berdasarkan kasus-kasus yang telah terjadi mengenai subjek yang hendak dipelajari. (5)Mempelajari sesuatu dengan cara melakukan eksplorasi terhadap subyek yang hendak dipelajari.[3].

\subsection{Corona virus Disease (COVID-19)}

Awalnya, penyakit ini dinamakan sementara sebagai 2019 novel coronavirus (2019-nCoV), kemudian WHO mengumumkan nama baru pada 11 Februari 2020 yaitu Coronavirus Disease (COVID19) yang disebabkan oleh virus Severe Acute Respiratory Syndrome Coronavirus-2 (SARS-CoV2) Virus ini dapat ditularkan dari manusia ke manusia. [5].

\section{METODE PENELITIAN}

\subsection{Studi Literatur}

Pada tahap ini penulis melakukan penggalian konsep penelitian melalui studi pustaka berdasarkan penelitian-penelitian yang telah dilakukan sebelumnya untuk dijadikan kajian pendukung dalam topik penelitian yang penulis lakukan.

\subsection{Wawancara}

Pada tahap ini dilakukan pengumpulan data melalui proses wawancara dengan pihak STIKOM UYELINDO KUPANG.

\subsection{Kuesioner}

Pada Tahap ini penulis melakukan survei atau riset menggunakan serangkaian pertanyaan tertulis yang bertujuan untuk mendapatkan tanggapan dari mahasiswa STIKOM Uyelindo Kupang Tentang Pemberlakuan Proses Pembelajaran Online berbasis Ubiquitous Learning. 


\section{PEMBAHASAN}

\subsection{Gambaran Kuliah Online berbasis Ubiquitous Learning di STIKOM Uyelindo Kupang}

Menyikapi surat Edaran Menteri Pendidikan dan Kebudayaan Republik Indonesia Nomor.3 tahun 2020 tentang Pencegahan Corona Virus Disease (Covid-19) serta Instruksi Gubernur Nusa Tenggra Timur Nomor:443/100/PK/2020 Tentang peningkatan Kewaspadaan resiko penularan infeksi Corona Virus Disease (Covid-19) pada Satuan Pendidikan di Provinsi Nusa Tenggara Timur, maka SIKOM Uyelindo Kupang sebagai lembaga pendidikan Tinggi berbasis IT mengambil sikap untuk melakukan Kuliah Online berbasis Ubiquitous Learning dengan memanfaatkan fasilitas internet dengan gunakan Aplikasi-Aplikasi seperti Googel Class, Zoom, AdLinkSevima, serta Aplikasi IClass yang merupakan aplikasi milik STIKOM Uyelindo sendiri. Pertanyaannya adalah seberapa puaskah Mahasiswa dalam mengikuti proses pembelajaran daring berbasis Ubiquitous Learning yang dilakukan selama masa pandemic Covid-19.

Untuk menjawab pertanyaan ini mari kita telusuri tanggapan kepuasan mahasiswa tentang pemberlakuan proses pembelajaran online berbasis Ubiquitous Learning.

Berikut ini Hasil Tanggapan Kepuasan dari 32 Mahasiswa tentang pemberlakuan proses pembelajaran online berbasis Ubiquitous Learning:

\begin{tabular}{|c|c|c|c|c|c|}
\hline No & Pertanyaan & SS & $\mathbf{S}$ & TS & STS \\
\hline 1 & $\begin{array}{l}\text { Aplikasi Pendukung } \\
\text { Pembelajaran } \\
\text { Online berbasis u- } \\
\text { learning mudah } \\
\text { digunakan }\end{array}$ & 22 & 8 & 2 & 0 \\
\hline 2 & $\begin{array}{l}\text { Aplikasi Kuliah } \\
\text { Online } \\
\text { menyediakan } \\
\text { Materi yang } \\
\text { lengkap dan } \\
\text { terperinci }\end{array}$ & 19 & 10 & 3 & 0 \\
\hline 3 & $\begin{array}{l}\text { Apliaksi Online } \\
\text { Menyediakan } \\
\text { Tombol yang }\end{array}$ & 6 & 20 & 5 & 1 \\
\hline
\end{tabular}

\begin{tabular}{|c|c|c|c|c|c|}
\hline No & Pertanyaan & SS & $\mathbf{S}$ & TS & STS \\
\hline & $\begin{array}{l}\text { bekerja sesuai } \\
\text { fungsinya }\end{array}$ & & & & \\
\hline 4 & $\begin{array}{l}\text { Materi atau Tutorial } \\
\text { Online yang } \\
\text { diberikan membuat } \\
\text { aktif mahasiswa } \\
\text { ketika belajar }\end{array}$ & 5 & 23 & 4 & 0 \\
\hline 5 & $\begin{array}{l}\text { Tutorial Online } \\
\text { adalah inovasi } \\
\text { pembelajaran yang } \\
\text { menyenangkan }\end{array}$ & 30 & 2 & 0 & 0 \\
\hline 6 & $\begin{array}{l}\text { Pembelajaran } \\
\text { Online berbasis u- } \\
\text { learning sangat } \\
\text { nyaman } \\
\text { dibandingkan } \\
\text { dengan pembelajran } \\
\text { biasa }\end{array}$ & 20 & 10 & 2 & 0 \\
\hline 7 & $\begin{array}{l}\text { Materi yang } \\
\text { diberikan dosen } \\
\text { sesuai dengan } \\
\text { kontrak kuliah yang } \\
\text { disampaikan }\end{array}$ & 10 & 19 & 2 & 1 \\
\hline 8 & $\begin{array}{l}\text { Tugas yang } \\
\text { diberikan oleh } \\
\text { bapak ibu dosen } \\
\text { sesuai dengan } \\
\text { toturial yang } \\
\text { diberikan }\end{array}$ & 4 & 26 & 2 & 0 \\
\hline 9 & $\begin{array}{l}\text { Soal Ujian yang } \\
\text { diberikan sesuai } \\
\text { dengan materi yang } \\
\text { diberikan }\end{array}$ & 20 & 9 & 1 & 2 \\
\hline 10 & $\begin{array}{l}\text { Jaringan Internet } \\
\text { yang disediakan } \\
\text { untuk mendukung } \\
\text { proses } \\
\text { Pembelajaran } \\
\text { Online berbasis u- } \\
\text { learning memadai }\end{array}$ & 6 & 10 & 12 & 4 \\
\hline
\end{tabular}

Pertanyaan Penununtun angket:

1. Aplikasi Pendukung Pembelajaran Online berbasis u-learning mudah digunakan.

2. Aplikasi Kuliah Online menyediakan Materi yang lengkap dan terperinci.

3. Apliaksi Online Menyediakan Tombol yang bekerja sesuai fungsinya. 
4. Materi atau Tutorial Online yang diberikan membuat aktif mahasiswa ketika belajar.

5. Tutorial Online adalah inovasi pembelajaran yang menyenangkan

6. Pembelajaran Online berbasis u-learning sangat nyaman dibandingkan dengan pembelajaran biasa.

7. Materi yang diberikan dosen sesuai dengan kontrak kuliah yang disampaikan.

8. Tugas yang diberikan oleh bapak ibu dosen sesuai dengan toturial yang diberikan.

9. Soal Ujian yang diberikan sesuai dengan materi yang diberikan.

10. Jaringan Internet yang disediakan untuk mendukung proses Pembelajaran Online berbasis u-learning memadai.

Dengan Indikator Penilaian: Sangat Setuju, Setuju, Tidak Setuju, Sangat Tidak Setuju.

Hasil Analis Kepuasan Mahasiswa tentang pelaksanaan proses pembelajaran online berbasis U-Learning akan di tampilkan pada grafik berikut:

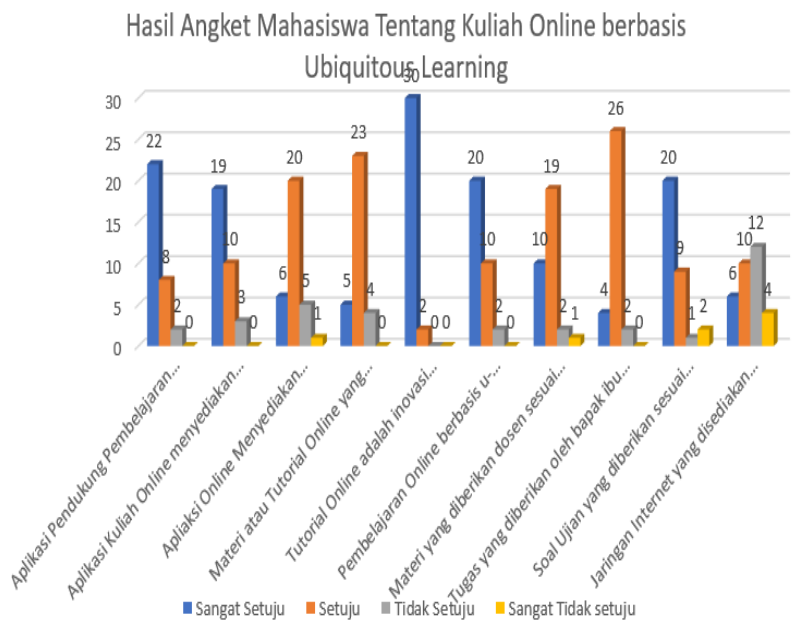

Gambar. Grafik Hasil Angket

\subsection{Presentase Hasil Tanggapan Kepuasan} Mahasiswa berdasarkan butir pertanyaan:

1. Pertanyaan Nomor 1

Yang Menjawab Sangat Setuju dari 32 Orang mencapai: $68,75 \%$, yang menjawab setuju mencapai: $25 \%$, yang menjawab tidak setuju: $6.25 \%$ dan yang menjawab sangat tidak setuju: $0 \%$.
2. Pertanyaan Nomor 2

Yang Menjawab Sangat Setuju dari 32 Orang mencapai: $59,37 \%$, yang menjawab setuju mencapai: $31,25 \%$, yang menjawab tidak setuju: $9,37 \%$ dan yang menjawab sangat tidak setuju: $0 \%$.

3. Pertanyaan Nomor 3

Yang Menjawab Sangat Setuju dari 32 Orang mencapai: $18,75 \%$, yang menjawab setuju mencapai: $62,5 \%$, yang menjawab tidak setuju: $15,62 \%$ dan yang menjawab sangat tidak setuju: $3,12 \%$.

4. Pertanyaan Nomor 4

Yang Menjawab Sangat Setuju dari 32 Orang mencapai: $15,62 \%$, yang menjawab setuju mencapai: $71,87 \%$, yang menjawab tidak setuju: $12,5 \%$ dan yang menjawab sangat tidak setuju: $0 \%$.

5. Pertanyaan Nomor 5

Yang Menjawab Sangat Setuju dari 32 Orang mencapai: $93,75 \%$, yang menjawab setuju mencapai: $6,25 \%$, yang menjawab tidak setuju: $0 \%$ dan yang menjawab sangat tidak setuju: 0 $\%$.

6. Pertanyaan Nomor 6

Yang Menjawab Sangat Setuju dari 32 Orang mencapai: $62,5 \%$, yang menjawab setuju mencapai: $31,25 \%$, yang menjawab tidak setuju: $6,25 \%$ dan yang menjawab sangat tidak setuju: $0 \%$.

7. Pertanyaan Nomor 7

Yang Menjawab Sangat Setuju dari 32 Orang mencapai: $31,25 \%$, yang menjawab setuju mencapai: 59,37\%, yang menjawab tidak setuju: $6,25 \%$ dan yang menjawab sangat tidak setuju: $3,12 \%$.

8. Pertanyaan Nomor 8

Yang Menjawab Sangat Setuju dari 32 Orang mencapai: $12,5 \%$, yang menjawab setuju mencapai: $81,25 \%$, yang menjawab tidak setuju: $6,25 \%$ dan yang menjawab sangat tidak setuju: $0 \%$. 
9. Pertanyaan Nomor 9

Yang Menjawab Sangat Setuju dari 32 Orang mencapai: $62,5 \%$, yang menjawab setuju mencapai: $28,12 \%$, yang menjawab tidak setuju: $3,12 \%$ dan yang menjawab sangat tidak setuju: $6,25 \%$.

10. Pertanyaan Nomor 10

Yang Menjawab Sangat Setuju dari 32 Orang mencapai: $18,75 \%$, yang menjawab setuju mencapai: $31,25 \%$, yang menjawab tidak setuju: $37,5 \%$ dan yang menjawab sangat tidak setuju: $12,5 \%$.

\section{KESIMPULAN}

Dari uraian-uraian yang telah dijabarkan diatas maka kesimpulan yang didapat adalah:

1. Perlu adanya media pendukung proses perkuliahan yang paten agar proses Perkulihan dapat berjalan sebagaimana mestinya.

2. Setiap Dosen atau Tenaga Pengajar perlu mempersiapkan diri sebaik mungkin agar proses perkuliahan dapat berjalan dengan baik.

3. Telah Menghasilkan angket secara terperinci untuk mengetahui tingkat kepuasan mahasiswa terhadap proses perkuliahan online berbasis u-learning di STIKOM Uyelindo Kupang.

\section{DAFTAR PUSTAKA}

[1] Bates, T., 1997. The Impact of Technological Change on Open and Distance Learning. Distance Education

[2] Bomsdorf, B. 2005. Adaptation of Learning Spaces: Supporting Ubiquitous Learning in Higher DistanceEducation. Dagstuhl Seminar Proceedings 05181 Mobile Computing and Ambient Intelligence: The Challenge of Multimedia

[3] Kuswara, E. 2005. Konsep Pendidikan Tinggi Berbasis E-learning: Peluang dan Tantangan. Prosiding Konferensi Nasional Teknologi Informasi dan Komunikasi Indonesia ITB, 3-4 Mei 2005
[4] Sappaile Intang Baso (2010). Konsep Penelitian Ex-Post Facto, JurnalPendidikan Matematika, Vol. 1 No. 2, ISSN 2086-8235

[5] Susilo Adityo at all, 2019. Coronavirus Disease 2019: Review of Current Literatures Terkini.JurnalPenyakitDalam Indonesia,elSSN:25490621. Departemen Ilmu Penyakit Dalam Fakultas Kedokteran Universitas Indonesia - RSUPN dr. Cipto Mangunkusumo, Jakarta 